УДК 343.985.7

DOI https://doi.org/10.32837/pyuv.v0i2(27).215

\author{
М. Л. Пасечник \\ аспірант кафедри криліналістики \\ Національного університету «Одеська юридична акаделія»
}

\title{
ЗАХОДИ ЗАБЕЗПЕЧЕННЯ БЕЗПЕКИ УЧАСНИКІВ КРИМІНАЛЬНОГО ПРОВАДЖЕННЯ ЯК ЕЛЕМЕНТ СЛІДЧОЇ ТАСМНИЦІ
}

Забезпечення безпеки учасників кримінального судочинства ще з 1993 р. вирішується на правовій основі, закладеній законами України «Про забезпечення безпеки осіб, які беруть участь у кримінальному судочинстві» та «Про державний захист працівників суду і правоохоронних органів» [1-2].

Дослідженню цієї проблеми значну увагу приділили такі автори, як Л.В. Брусніцин, В.В. Войніков, О.О. Гриньків, О.А. Зайцев, В.С. Зеленецький, Ю.М. Крамаренко, М.В. Куркін, А.О. Ляш, М.В. Новікова, Т.I. Панасюк, О.О. Подобний, Р.В. Тарасенко. Водночас необхідно констатувати, що в умовах дії чинного кримінального процесуального законодавства досвід відповідної діяльності органів досудового розслідування, оперативних підрозділів, а також напрями її нормативно-правового вдосконалення ще на достатньому рівні в науковій літературі не систематизовані.

Завданням статті є обгрунтування заходів забезпечення безпеки учасників кримінального провадження як елементу слідчої таємниці.

Згідно із положеннями указаних нормативних актів, забезпечення безпеки осіб, які беруть участь у кримінальному судочинстві, тобто у виявленні, попередженні, припиненні або розслідуванні кримінальних правопорушень, а також у судовому розгляді кримінальних проваджень, це здійснення правоохоронними органами правових, організаційно-технічних та інших заходів, спрямованих на захист життя, житла, здоров'я та майна цих осіб від протиправних посягань із метою створення необхідних умов для належного відправлення правосуддя [2].

Ст. 7 Закону України «Про забезпечення безпеки осіб, які беруть участь у кримінальному судочинстві» та ст. 5 Закону України «Про державний захист працівників суду і правоохоронних органів» визначаються види заходів забезпечення безпеки. Дослідники розглядуваної тематики, застосувавши порівняльний аналіз зазначених статей, дійшли висновку, що за умов неврахування такого архаїчного за своєю сутністю «спеціального заходу забезпечення безпеки» відповідно до другого з указаних законів, як «встановлення телефону за місцем проживання», а також заходу, що застосовується щодо осіб, які беруть участь у кримінальному судочинстві, - закритий судовий розгляд, то за зазначеними законами є ще вісім майже однаково сформульованих у вказаних джерелах заходів безпеки: 1) особиста охорона, охорона житла і майна; 2) видача спеціальних засобів індивідуального захисту і сповіщення про небезпеку; 3) використання технічних засобів контролю i прослуховування телефонних та інших переговорів, візуальне спостереження; 4) заміна документів та зміна зовнішності; 5) зміна місця роботи або навчання; 6) переселення в інше місце проживання; 7) поміщення до дошкільної виховної установи або установи органів соціального захисту населення; 8) забезпечення конфіденційності відомостей про особу [3, с. 75].

При цьому вчені неодноразово звертали увагу на недостатню коректність закріплення в зазначених нормативних актах переліків заходів забезпечення безпеки. Зокрема, Р.В. Тарасенко наголошує на доцільності їх класифікації таким чином: заходи, спрямовані на забезпечення конфіденційності відомостей про учасників кримінального судочинства; заходи, спрямовані на охорону життя, здоров'я, житла та майна учасників кримінального судочинства; довгострокові заходи, пов'язані із переселенням в інше місце проживання. Дослідник підкреслює, що рішення про застосування та практична реалізація у межах кримінального провадження окремих заходів безпеки у різному ступені обмежують права $\mathrm{i}$ законні інтереси обвинуваченого, у зв'язку з чим потребують чіткого кримінального процесуального врегулювання [4, с. 374].

Як слушно зазначають дослідники розглядуваного питання, найбільш дієвими та застосовуваними є заходи безпеки, зазначені у п.п. 1-3. Їхня ефективність забезпечується за умов комплексного застосування, в тому числі у поєднанні iз заходами забезпечення конфіденційності відомостей про особу. Обов'язок здійснення цих заходів у рамках оперативно-розшукового забезпечення кримінального провадження покладається на працівників уповноважених оперативних підрозділів. Тому 0.0. Подобний наголошує, що використання технічних засобів контролю, прослуховування телефонних та інших переговорів, візуальне спостереження у правових умовах сьогодення мають реалізовуватися саме шляхом кваліфікованого проведення відповідних НСРД, 
передбачених КПК у ст. ст. 260, 268, 269, 270. Вжиття зазначених заходів безпеки за правовою процедурою, передбаченою для НСРД, дасть змогу за умов фіксації фактичних даних про протиправні дії злочинців, спрямовані проти учасників кримінального судочинства, працівників суду, правоохоронних органів або членів їх сімей, одразу вводити їх у кримінальне провадження як докази відповідної злочинної діяльності [3].

Крім того, зазначені заходи безпеки, реалізовані за правовою процедурою НСРД, мають застосовуватися в комплексі із заходами забезпечення конфіденційності даних про особу. Такі заходи відповідно до ст. 15 коментованого закону можуть здійснюватися шляхом: а) обмеження відомостей про особу в матеріалах перевірки (заявах, поясненнях тощо), а також протоколах слідчих дій та інших матеріалах кримінального провадження, заміни прізвища, імені, по батькові в цих документах псевдонімами за постановою органу, що здійснює ОРД, слідчого, прокурора або за ухвалою слідчого судді, суду про зміну анкетних даних; б) проведення упізнання особи поза візуальним та аудіоспостереженням того, кого впізнають, 3 дотриманням вимог кримінально процесуального законодавства; в) неоголошення будь-яким способом дійсних анкетних даних про осіб, які взяті під захист і підлягають виклику в судове засідання; г) виклику до суду цієї особи виключно через орган, який здійснює заходи безпеки; г') накладення тимчасової заборони на видачу відомостей про особу, взяту під захист, адресними бюро, паспортними службами, підрозділами реєстрації автотранспорту, довідковими службами [2].

Водночас необхідно наголосити, що п. 20 ст. 7 КПК передбачає, в тому числі, таку загальну засаду кримінального провадження, як «гласність і відкритість судового провадження та його повне фіксування технічними засобами». При цьому ч. 2 ст. 27 КПК, що розтлумачує цей принцип, встановлює законоположення, згідно з яким кримінальне провадження в судах усіх інстанцій здійснюється відкрито. Однак слідчий суддя, суд може прийняти рішення про здійснення кримінального провадження в закритому судовому засіданні впродовж усього судового провадження або його окремої частини, зокрема: якщо здійснення провадження у відкритому судовому засіданні може призвести до розголошення таємниці, що охороняється законом (згідно з п. 4) та необхідності забезпечення безпеки осіб, які беруть участь у кримінальному провадженні (відповідно до п. 5) [5].

Не на користь чинного законодавства свідчить компаративний аналіз положень ст. 16 Закону України «Про забезпечення безпеки осіб, які беруть участь у кримінальному судочинстві», яка регламентує питання закритого судового засідання, та положень КПК. У зв’язку з прийняттям
Кримінального процесуального закону 2012 р. суттєво змінено зміст зазначеної статті. Так, чинною редакцією ч. 2 встановлено, що у випадку та в порядку, передбаченому КПК, для забезпечення безпеки учасника кримінального провадження суд може прийняти рішення про проведення допиту учасника кримінального провадження 3 використанням відеоконференції при трансляції з іншого приміщення, в тому числі у спосіб, що унеможливлює ідентифікацію особи, яка дає показання [6]. Водночас у минулій редакції було зафіксовано законоположення, відповідно до якого для забезпечення безпеки свідка чи потерпілого суд мав змогу винести мотивовану ухвалу про проведення допиту цих осіб за відсутності підсудного. За цих же підстав допускався допит одного підсудного за відсутності інших. Після повернення підсудного до залу судового засідання суд зобов'язувався ознайомити його з показаннями, які було дано за час його відсутності, і надати йому змогу дати пояснення з приводу цих показань. Крім того, ч. 3 коментованої статті встановлювала законоположення, відповідно до якого суд у виняткових випадках мав змогу звільняти потерпілих і свідків, щодо яких здійснюються заходи безпеки, від обов'язку з'являтися в судове засідання за наявності письмового підтвердження показань, даних ними раніше [2].

Необхідно погодитися з вченими, які наголошують, що заходи безпеки, передбачені ч.ч. 2 і 3 коментованої статті у попередній редакції, надавали більш дієвий інструментарій захисту та пропонували залишити зазначені можливості здійснення закритого судового розгляду з одночасним наданням альтернативи у вигляді проведення допиту учасника кримінального провадження 3 використанням відеоконференції. Можливість звільнення осіб, щодо яких здійснюються заходи безпеки, від обов'язку з'являтися у судове засідання за наявності письмового підтвердження показань, даних ними раніше, пропонувалося реалізувати, використовуючи правовий механізм, наданий ст. 255 КПК «Допит свідка, потерпілого під час досудового розслідування в судовому засіданні» [3, с. 76].

Необхідно згадати той факт, що законодавець у КПК України (1960р.) у відповідних змінах до нього, внесених у 2000 р. [7], вже раніше реалізовував підхід до вдосконалення кримінального процесуального закону, відповідно до якого вищерозглянуті основні положення законів України «Про забезпечення безпеки осіб, які беруть участь у кримінальному судочинстві» та «Про державний захист працівників суду i правоохоронних органів» поряд з іншими актуальними аспектами проблематики були введені до КПК у ст. 52-1 «Забезпечення безпеки осіб, які беруть участь у кримінальному судочинстві», ст. 52-2 «Права і обов'яз- 
ки осіб, щодо яких здійснюються заходи безпеки", ст. 52-3 «Нерозголошення відомостей про особу, щодо якої здійснюються заходи безпеки», ст. 52-4 «Порядок скасування заходів безпеки», ст. 52-5 «Оскарження рішень про відмову в застосуванні заходів безпеки або про їх скасування» .

Натомість у КПК 2012 р. питання забезпечення безпеки учасників кримінального судочинства знайшли своє відбиття лише фрагментарно в таких статтях: 1) вищезгаданий п. 5 ч. 2 ст. 27 ; 2) п. 9 ч. 2 ст. 65 , відповідно до якої не можуть бути допитані як свідки, зокрема й особи, до яких застосовані заходи безпеки, - щодо дійсних даних про їх особи; 3) ст. 255 «Допит свідка, потерпілого під час досудового розслідування в судовому засіданні», яка передбачає таку можливість, зокрема у разі існування небезпеки для життя і здоров'я зазначених учасників процесу; 4) п. 2 ч. 1 та ч. 8 ст. 336 , де закріплені положення, відповідно до яких судове провадження може здійснюватися в режимі відеоконференції під час трансляції з іншого приміщення, у тому числі яке знаходиться поза межами приміщення суду (дистанційне судове провадження), в разі необхідності забезпечення безпеки осіб; особа, якій забезпечується захист, може бути допитана в режимі відеоконференції з такими змінами зовнішності і голосу, за яких її неможливо впізнати; $5)$ ч. 9 ст. 352 , згідно з положеннями якої у виняткових випадках для забезпечення безпеки свідка, що підлягає допиту, суд за власною ініціативою або за клопотанням сторін кримінального провадження чи самого свідка постановляє вмотивовану ухвалу про проведення допиту свідка з використанням технічних засобів з іншого приміщення, у тому числі за межами приміщення суду, або в інший спосіб, що унеможливлює його ідентифікацію та забезпечує сторонам кримінального провадження змогу ставити запитання і слухати відповіді на них; якщо є загроза ідентифікації голосу свідка, допит може супроводжуватися створенням акустичних перешкод.

У зв'язку з означеним, необхідно погодитися з думкою тих дослідників, які підкреслювали, що положення п. 5 ч. 2 ст. 27 КПК 2012 р. на фоні внесення вищевказаних змін у ст. 16 Закону України «Про забезпечення безпеки осіб, які беруть участь у кримінальному судочинстві» отримує лише декларативне значення та не передбачає правового механізму його реалізації, а несистемність та непослідовність викладення розглядуваного кола питань у чинному кримінальному процесуальному законі, у наукових дослідженнях із $2014 \mathrm{p}$. призводила до висновку про необхідність імплементації положень вказаного закону та Закону України «Про державний захист працівників суду і правоохоронних органів» до КПК у вигляді окремого розділу [8; 4 , с. 83$]$.
Першочергового закріплення безпосередньо в чинному КПК потребують положення ст. 15 Закону України «Про забезпечення безпеки осіб, які беруть участь у кримінальному судочинстві» щодо обмеження відомостей про особу в матеріалах перевірки (заявах, поясненнях тощо), а також протоколах слідчих дій та інших матеріалах кримінального провадження, заміни прізвища, імені, по батькові в цих документах псевдонімами за постановою органу, що здійснює ОРД, слідчого, прокурора або за ухвалою слідчого судді, суду про зміну анкетних даних.

Водночас реальним кримінальним процесуальним засобом вирішення конфлікту між публічним інтересом, пов'язаним із необхідністю гарантування безпеки учасника кримінального судочинства шляхом забезпечення конфіденційності відомостей про його особу на стадії досудового розслідування, у томі числі на етапі відкриття матеріалів іншій стороні в порядку, передбаченому ст. 290 КПК, та приватним інтересом сторони захисту, пов'язаним з ознайомленням із матеріалами, що розкривають конфіденційність відомостей про цю особу, є зарахування зазначеного питання до переліку рішень слідчого або прокурора, які можуть бути оскаржені до слідчого судді, передбаченого ч. 1 ст. 303 КПК, зі закріпленням законоположення, відповідно до якого зазначені скарги розглядаються слідчим суддею апеляційного суду відповідно до положень ст. ст. 247-248 КПК.

Підсумовуючи, необхідно зазначити, що заходи забезпечення безпеки учасників кримінального провадження є елементами слідчої таємниці. Питання забезпечення безпеки учасників кримінального провадження мають бути імплементовані до КПК у вигляді окремого розділу.

\section{Jimepamypa}

1. Про державний захист працівників суду і правоохоронних органів : Закон України від 23.12.1993 р. № 3781-XII в редакції від 11.06.2009 р. № 1254-17 / Верховна Рада України. URL : http://zakon1.rada.gov.ua (дата звернення: 20.06.2019).

2. Про забезпечення безпеки осіб, які беруть участь у кримінальному судочинстві : Закон України від 23 грудня 1993 р. № 3782-XII : в редакції Закону України від 13.04.2012 р. № 4652-VI / Верховна Рада України. URL: http://zakon1.rada.gov.ua (дата звернення: 20.06.2019).

3. Подобний 0.О. Безпека учасників кримінального судочинства як завдання оперативно-розшукового забезпечення кримінального провадження. Вісник кримінального судочинства. 2015. № 3. С. 74-80.

4. Тарасенко Р.В. Безпека учасників кримінального судочинства: кримінальні процесуальні та оперативно-розшукові основи : моногр. Одеса : ОДУВС, 2015. $510 \mathrm{c}$.

5. Кримінальний процесуальний кодекс України : Закон України від 13.04.2012 р.: за станом на 16.11.2017 р. № 2213-VIII / Верховна Рада України. URL: http://zakon1.rada.gov.ua (дата звернення: 20.06.2019). 
6. Про внесення змін до деяких законодавчих актів України у зв'язку з прийняттям Кримінального процесуального кодексу України : Закон України від 13 квітня 2013 р. № 4652-VI / Верховна Рада України. URL: http://zakon1.rada.gov.ua (дата звернення: 20.06.2019).

7. Про внесення змін до деяких законодавчих актів України : Закон України від 13 січня 2000 р. № 1381 XIV / Верховна Рада України. URL: http://zakon1. rada.gov.ua (дата звернення: 20.06.2019).

8. Подобний 0.0. Оперативно-розшукове забезпечення кримінального провадження про корисливо-насильницьку організовану злочинну діяльність. Форум права. 2013. № 4. URL: http://nbuv.gov.ua/j-pdf/ FP_index.htm_2013_4_52.pdf.

\section{Анотація}

Пасечник М. Л. Заходи забезпечення безпеки учасників кримінального провадження як елемент слідчої таємниці. - Стаття

У статті на основі аналізу останніх досліджень і публікацій заходи забезпечення безпеки учасників кримінального провадження обгрунтовані як елемент слідчої таємниці.

Найбільш вдалим підходом до класифікації заходів забезпечення безпеки визначений той, відповідно до якого вони розподіляються на: заходи, спрямовані на забезпечення конфіденційності відомостей про учасників кримінального судочинства; заходи, спрямовані на охорону життя, здоров'я, житла та майна учасників кримінального судочинства; довгострокові заходи, пов'язані із переселенням в інше місце проживання. Доведено слушність пропозицій щодо необхідності реалізації таких заходів безпеки, як використання технічних засобів контролю, прослуховування телефонних та інших переговорів, візуального спостереження саме шляхом кваліфікованого проведення відповідних негласних слідчих (розшукових) дій, передбачених КПК у ст. ст. $260,268,269,270$.

Підтримано точку зору вчених, які констатували, що рішення про застосування та практичну реалізацію в межах кримінального провадження окремих заходів, передбачених КПК та Законом України «Про забезпечення безпеки учасників кримінального судочинства» (передусім, закритий судовий розгляд та забезпечення конфіденційності відомостей про особу), у різному ступені обмежують права і законні інтереси підозрю- ваного (обвинуваченого), у зв'язку з чим потребують чіткого кримінального процесуального врегулювання. Доведено, що питання забезпечення безпеки учасників кримінального провадження мають бути імплементовані до КПК України у вигляді окремого розділу.

Ключові слова: слідча таємниця, інформація, заходи забезпечення безпеки учасники кримінального провадження, досудове розслідування.

\section{Summary}

Pasechnik M. L. Security measures for participants in criminal proceedings as an element of investigative secrecy. - Article.

In the article, based on the analysis of recent research and publications, the security measures of participants in criminal proceedings are justified as an element of investigative secrecy.

The most successful approach to the classification of security measures is the one according to which they are divided into: measures aimed at ensuring the confidentiality of information about participants in criminal proceedings; measures aimed at protecting the life, health, housing and property of participants in criminal proceedings; long-term activities related to relocation to another place of residence.

The correctness of the proposals for the necessity to implement such security measures as the use of technical means of control, listening to telephone and other negotiations, visual observation by means of the qualified carrying out of the relevant unspoken investigative (search) actions provided by the CCP in Art. 260, 268, 269, 270.

The point of view of scientists was stated that the decision on the application and practical implementation within the framework of criminal proceedings of certain measures envisaged by the CPC and the Law of Ukraine "On ensuring the safety of participants in criminal proceedings" (primarily closed trial and confidentiality of personal information), in various the degree limits the rights and legitimate interests of the suspect (accused), and therefore require a clear criminal procedural settlement. It is proved that the issues of ensuring the safety of participants in criminal proceedings should be implemented in the CPC of Ukraine in a separate section.

Key words: investigative secrecy, information, security measures, participants in criminal proceedings, pre-trial investigation. 